Kayoko Imai · Tohru Mitsunaga • Hiroyuki Takemoto

Toshihiro Yamada $\cdot$ Shin-ichiro Ito $\cdot$ Hideo Ohashi

\title{
Extractives of Quercus crispula sapwood infected by the pathogenic fungi Raffaelea quercivora I: comparison of sapwood extractives from noninfected and infected samples
}

Received: March 28, 2008 / Accepted: October 8, 2008 / Published online: December 27, 2008

\begin{abstract}
The extracts of Quercus crispula infected by the ambrosia fungus, Raffaelea quercivora, were investigated. Phenol and tannin analyses indicated that normal sapwood (NS) contained a considerable amount of hydrolysable tannins, while infected colored sapwood (IS) contained less hydrolysable tannins and more phenols than NS. In treating pentagalloyl glucose (PGG), which is a model compound of hydrolysable tannins, with a culture medium of R. quercivora, PGG was rapidly hydrolyzed to produce gallic acid. The resulting gallic acid decreased in concentration over the subsequent cultivation period eventually disappeared. Measuring tannase and laccase activities of the culture medium of $R$. quercivora, tannase activity increased gradually from the beginning, while laccase activity increased rapidly at 5 days of incubation and disappeared at 8 days. An oxidative product from gallic acid treated with laccase was isolated by preparative high performance liquid chromatography, and was identified as purprogallincarboxylic acid (PGCA) by nuclear magnetic resonance spectroscopy and electronimpact mass spectrometry. PGCA was present in a $70 \%$ aqueous acetone extract of IS, and showed slight growth inhibition against $R$. quercivora.
\end{abstract}

K. Imai $\cdot$ T. Mitsunaga $(\bowtie) \cdot H$. Ohashi

Department of Applied Life Science, Faculty of Applied Biological

Sciences, Gifu University, 1-1 Yanagido, Gifu 510-1193, Japan

Tel. +81-58-293-2920; Fax +81-58-293-2920

e-mail: mitunaga@gifu-u.ac.jp

H. Takemoto

Center for Ecological Research, Kyoto University, Otsu, Shiga

520-2113, Japan

T. Yamada

Experimental Section at Chiba, The University Forest, The

University of Tokyo, Kamogawa, Chiba 299-5503, Japan

S. Ito

Department of Sustainable Resource Sciences, Faculty of

Bioresources, Mie University, Tsu, Mie 514-8507, Japan

Part of this study was presented at the 57th Annual Meeting of the Japan Wood Research Society, Hiroshima, Japan, 2007
Key words Raffaelea quercivora - Quercus crispula · Gallotannins $\cdot$ Ellagitannins $\cdot$ Tannase

\section{Introduction}

The mass mortality of oak trees has been widespread along the northwestern coastline of the Japanese island of Honshu since the late 1980s. ${ }^{1}$ This large scale forest disease is caused by the ambrosia fungi, Raffaelea quercivora, which is a symbiotic microorganism with the ambrosia beetle, Platypus quercivorus (Murayama) (Coleoptera: Platypodidae). ${ }^{2}$ The beetle carries the fungi in its mycangium, which is a storage organ used to carry symbiotic fungi for breeding its larva. The ambrosia beetle bores into the trunk of the dead or wilting oak tree and brownish-yellow coloration is generated along the beetle gallery in the sapwood. The colored sapwood may contain a number of substances, such as repellents against the beetle, because newly attacking beetles have an inclination to avoid colored parts of the trunk. However, knowledge of the chemical components and the biological function of the colored part are limited to date.

In some other cases, colorations in sapwood are formed by chemical reactions ${ }^{3,4}$ or physiological reactions in living cells. $^{5}$ Kiln brown stain (KBS) that develops in kilndried radiata pine is a thermochemical reaction product of water-soluble compounds. ${ }^{4}$ The presence of carbohydrates, cyclitols, amino acids, protein, and phenolics in the water-soluble compounds was reported and the reducing sugars and amino acids in the sap and hot-water extracts suggested that these compounds react together to form colored compounds. ${ }^{6}$ This is the so-called Maillard-Amadori reaction, ${ }^{7,8}$ which is commonly observed as food browning in cooking.

Colorations caused by enzymatic reactions have been reported for Douglas fir, Pseudotsuga menziesii, ${ }^{9,10}$ and oak heartwoods. ${ }^{11}$ Compounds existing in living cells of Douglas fir sapwood, such as $o$-dihydroxy phenols, (-)-epicatechin, and dihydroquercetin, react with naturally occurring 
enzymes in the trees and form brown-colored materials in the exposed surface of the lumber. Bauch et al. ${ }^{11}$ found that the yellow coloration in Quercus robur L. and Quercus petraea is caused by a mold fungus, Paecilomyces variotii Bain., and that the reacting compounds are hydrolysable tannins. The tannase of Paecilomyces variotii Bain. ${ }^{12}$ would release the reactants that would then form the coloration.

This study clarifies the relationship between the extracts of Quercus crispula sapwood and crude enzyme of $R$. quercivora to understand the role of the extracts in the colored sapwood of Q. crispula.

\section{Materials and methods}

\section{Analytical instruments}

High performance liquid chromatography (HPLC) used a reversed-phase column (Inertsil ODS-3V, $4.6 \mathrm{~mm}$ i.d. $\times$ $250 \mathrm{~mm}$, GL Science, Japan) and a diode array detector (SPD-M10A vp, Shimadzu). The following solvent system was used: a linear gradient elution for $45 \mathrm{~min}$ from $5 \%$ to $100 \%$ methanol in $0.05 \%$ trifluoroacetic acid (TFA) in $\mathrm{H}_{2} \mathrm{O}$ at a flow rate of $1 \mathrm{ml} / \mathrm{min}$, monitored at $280 \mathrm{~nm}$.

Preparative HPLC was performed on a Develosil packed column (packing Lop ODS size 24S) with elution at $10 \mathrm{ml} /$ min under isocratic condition (50 parts of acetonitrile containing $0.1 \%$ TFA and 50 parts of $0.1 \%$ TFA).

Ultraviolet (UV) spectra were measured on a Jasco V520 spectrophotometer and electron-impact mass spectrometry (EI-MS) was performed on a Shimadzu GCMSQP5050 instrument. ${ }^{1} \mathrm{H}$ and ${ }^{13} \mathrm{C}$ nuclear magnetic resonance (NMR) spectra were recorded on a JEOL ECA-500 NMR spectrometer $(500 \mathrm{MHz})$, and chemical shifts are given in $\delta(\mathrm{ppm})$ values relative to that of the solvent [methanol- $d_{4}$ $\left.\left(\delta_{\mathrm{H}} 3.35 ; \delta_{\mathrm{C}} 49.0\right)\right]$.

\section{Extraction of Quercus crispula sapwood}

Normal sapwood of Quercus crispula was collected in the Kuraiyama experimental forest, Gifu University, in November 2006. This wood was separated into bark, sapwood, and heartwood. The sapwood was milled into a powder $(580.6 \mathrm{~g})$ (ZM200 Ultra Centrifugal Mill, Retsch), which was then soaked in $70 \%$ aqueous acetone (35.9 1). After evaporating the acetone, the solution was extracted successively with diethyl ether $\left(\mathrm{Et}_{2} \mathrm{O}\right)(31 \times 3)$, ethyl acetate $(\mathrm{EtOAc})(31 \times$ $8)$, and $n$-butanol $(n-\mathrm{BuOH})(31 \times 4)$ to give the respective extracts. All extracts were analyzed by HPLC. The EtOAcsoluble fraction (EtOAc-S) was used as a sample in subsequent experiments.

Infected colored sapwood of Q. crispula (Fig. 1) was collected at the Toyama Forest and Forestry Products Research Center in November 2007. The wood (infected colored sapwood) was separated and ground and the powder $(725.6 \mathrm{~g})$ was extracted with $70 \%$ aqueous acetone (11.0 l). An aliquot of the extract was analyzed by HPLC.

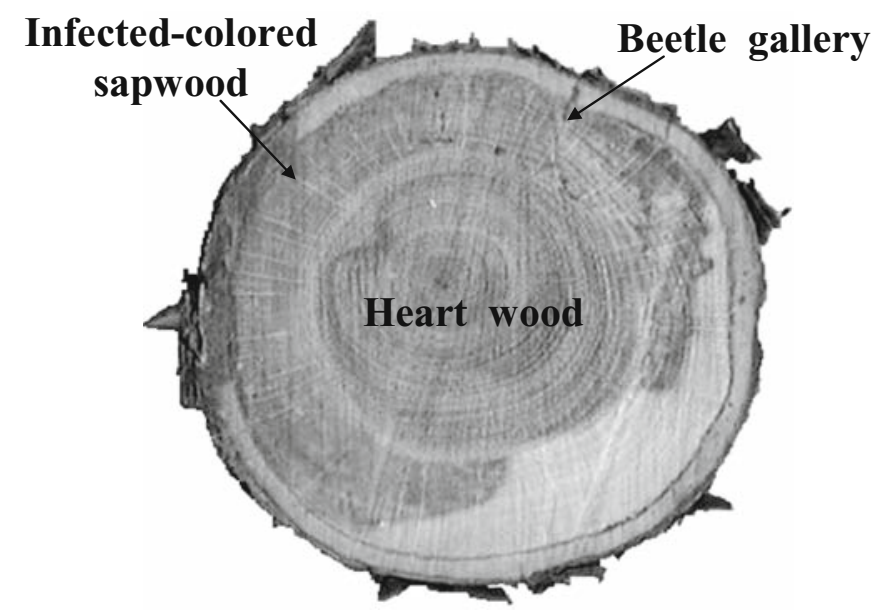

Fig. 1. Cross section of Quercus crispula attacked by Platypus quercivorus

No large difference was found when we analyzed extracts of $Q$. crispula sapwood obtained earlier ftom Toyama, Kyoto, Ishikawa, and Gifu (data not shown). As a result, noninfected and infected $Q$. crispula was used in this study regardless of its original location.

\section{Chemical analyses of extracts}

Tannin analyses were conducted as reported in previous studies. ${ }^{13,14}$ Total phenol and flavanol contents were measured by the Folin-Ciocalteu method and the vanillinhydrochloric acid method, respectively, using (+)-catechin as a standard reference.

Total phenol and total flavanol were calculated as follows:

Total phenol or total flavanol $(\%)=100 \times Y / S$,

where $Y$ represents the concentration of $(+)$-catechin $(\mathrm{mg} / \mathrm{ml})$ calculated from a calibration curve and $S$ represents concentration $(\mathrm{mg} / \mathrm{ml})$ of the sample [normal sapwood (NS) or infected sapwood (IS) extracts].

The adsorption of bovine serum albumin (BSA) by the extracts was evaluated by measuring the amount of BSA remaining in the supernatant after centrifugation of the reacting mixture; the residue contained precipitates formed by reaction of extract components with BSA. NS or IS extract $(1 \mathrm{mg} / \mathrm{ml}$ in $50 \%$ ethanol) and BSA aqueous solution $(5 \mathrm{mg} / \mathrm{ml})$ were mixed in equal volumes and kept at room temperature for $1 \mathrm{~h}$. Then BSA concentration was measured by HPLC analysis. BSA adsorption was calculated as follows:

BSA adsorption $(\%)=(A-B) / A \times 100$,

where $A$ is the BSA concentration in the control solution, and $B$ is the BSA concentration in the solution after mixing with samples (NS or IS extracts). The concentration of BSA was calculated from a calibration curve. 
Hydrolysis was conducted as follows. Five milligrams of NS extract was treated with $5 \mathrm{ml}$ of $3 \mathrm{~N}$ sulfuric acid at $110^{\circ} \mathrm{C}$ for $10 \mathrm{~h}$. After the temperature was lowered to room temperature, $6 \mathrm{~N}$ sodium hydroxide was added. The hydrolysate was analyzed by HPLC.

Enzymatic reaction of pentagalloyl glucose treated with crude enzyme of Raffaelea quercivora

Pentagalloyl glucose (PGG) was isolated from tannic acid by preparative HPLC. Isolated PGG was analyzed by NMR spectroscopy. ${ }^{15}$

For cultivation of Raffaelea quercivora, liquid medium including vitamins and minerals ${ }^{16}$ was used. Ten milliliters of liquid medium was sterilized by autoclave $\left(121^{\circ} \mathrm{C}\right.$, $15 \mathrm{~min}$ ). After sterilization, $20 \mu \mathrm{l}$ of PGG solution $(200 \mathrm{mg} /$ $\mathrm{ml}$, soluble in $50 \%$ methanol) was added and $R$. quercivora was inoculated. After incubation for 1, 2, 4, 6, 9, and $11 \mathrm{~h}$ and every day up to 12 days, an aliquot of the medium was analyzed by HPLC. The amounts of PGG and gallic acid in the medium were calculated from calibration curves derived from HPLC analysis of authentic PGG and gallic acid.

Hydrolysable tannins of Quercus crispula treated by crude enzyme of Raffaelea quercivora or commercial tannase

Raffaelea quercivora was inoculated into $10 \mathrm{ml}$ of sterilized culture medium including $20 \mu \mathrm{l}$ of EtOAc-S solution (20 mg/100 $\mu \mathrm{l}$ in $50 \% \mathrm{MeOH}$ ). After 10 days of incubation at $28^{\circ} \mathrm{C}$, an aliquot of culture medium was centrifuged (12500 rpm, $5 \mathrm{~min}$ ) Then $600 \mu \mathrm{l}$ of supernatant was extracted with $400 \mu \mathrm{l}$ of EtOAc; $200 \mu \mathrm{l}$ of the EtOAc-soluble fraction was dried and analyzed by HPLC.

On the other hand, EtOAc-S was treated with commercial tannase derived from Aspergillus oryzae (Wako, Japan) as follows. EtOAc-S was dissolved in $0.05 \mathrm{~mol} / \mathrm{l}$ citric acid buffer ( $\mathrm{pH} 5.5$ ) to give a concentration of $1.6 \mathrm{mg} / 450 \mu \mathrm{l}$. One thousand microliters of tannase solution $(3 \mathrm{mg} / 10 \mathrm{ml}$ in citric buffer) was added to $4000 \mu \mathrm{l}$ of EtOAc-S solution and kept at $30^{\circ} \mathrm{C}$, then $200 \mu \mathrm{l}$ of EtOAc was added to stop the reaction. Finally, an aliquot of the EtOAc-soluble fraction was collected and analyzed by HPLC.

\section{Enzyme activities}

Culture medium including minerals and vitamins ${ }^{16}(10 \mathrm{ml})$ was sterilized and inoculated with precultured $R$. quercivora [on potato dextrose agar (PDA) medium]. The culture medium was incubated for 10 days, during which an aliquot of the culture medium was periodically collected and filtered and the enzyme activity of the filtrate measured.

For the measurement of tannase activity, crude enzyme solution preincubated at $35^{\circ} \mathrm{C}$ for $10 \mathrm{~min}$ and $100 \mu \mathrm{l}$ of $10 \mathrm{mg} / \mathrm{ml}$ tannic acid solution in $0.05 \mathrm{M}$ citrate buffer $(\mathrm{pH}$
5.5) were mixed and incubated at $35^{\circ} \mathrm{C}$ for $1 \mathrm{~h} ; 1 \mathrm{~N}$ hydrochloric acid was added to stop the enzymatic reaction. The concentration of gallic acid in the reaction mixture was measured by HPLC analysis.

Laccase activity was measured using syringaldazine as substrate. Two hundred microliters of crude enzyme extract, $1.2 \mathrm{ml}$ of $0.1 \mathrm{M}$ acetate buffer $(\mathrm{pH} 5.7)$, and $200 \mu \mathrm{l}$ of $0.05 \mathrm{mM}$ syringaldazine ethanol solution were mixed. The rate of oxidation of syringaldazine to quinone was monitored at $525 \mathrm{~nm}$.

For peroxidase activity, $1 \mathrm{M}$ guaiacol solution, $0.1 \mathrm{M}$ phosphate buffer ( $\mathrm{pH} 7.4$ ), $30 \mathrm{mM}$ hydrogen peroxide solution, and crude enzyme solution were kept at $20^{\circ} \mathrm{C}$ before the activity test. One milliliter of $1 \mathrm{M}$ guaiacol solution, $1 \mathrm{ml}$ of $0.1 \mathrm{M}$ phosphate buffer, and $1 \mathrm{ml}$ of crude enzyme solution were mixed and $0.027 \mathrm{ml}$ of $30 \mathrm{mM}$ hydrogen peroxide was added to the reaction solution to start the reaction. Oxidation of guaiacol was measured by the increase in the absorbance at $470 \mathrm{~nm}$.

\section{Identification}

Five hundred milliliters of culture medium including minerals and vitamins ${ }^{16}$ was sterilized and precultured Pycnoporus coccineus, which is a known white rot fungus that produces a laccase, on PDA medium was inoculated and cultured at room temperature with shaking. After 5 days of incubation, the fungus body was removed by filtration and the resulting filtrate was dialyzed against buffer solution with Spertra/Por (molecular weight cutoff 12000-14000) for $24 \mathrm{~h}$.

In order to identify the product of the enzymatic reaction, $200 \mathrm{mg}$ of gallic acid dissolved in $0.05 \mathrm{M}$ sodium acetate buffer ( $\mathrm{pH} 5.0$ ) was added to $5 \mathrm{ml}$ of extracellular crude enzyme from Pycnoporus coccineus and incubated at $37^{\circ} \mathrm{C}$ for 1 week. The reaction mixture was evaporated and the residue was applied to a Sephadex LH-20 column $(26 \mathrm{~mm}$ i.d. $\times 200 \mathrm{~mm}$ ) using water as eluent to separate the yellowcolored fraction, mainly containing the product. The main compound, purprogallincarboxylic acid (PGCA), was isolated as a brownish crystal by preparative HPLC with an ODS column, and was identified by NMR spectroscopy and EI-MS.

Purprogallincarboxylic acid. UV (MeOH) $\lambda \max : 224,304$, $398 \mathrm{~nm}$. EI-MS (70 eV) m/z: $264[\mathrm{M}]^{+}, \mathrm{C}_{12} \mathrm{H}_{8} \mathrm{O}_{7} \cdot{ }^{1} \mathrm{H}$ NMR (dimethyl sulfoxide- $d_{6}, 500 \mathrm{MHz}$ ): $\delta 7.14(1 \mathrm{H}, \mathrm{H}-1), 7.77$ (1H, H-7), 8.22 (1H, H-9). ${ }^{13} \mathrm{C}$ NMR $\left(\mathrm{CDCl}_{3}, 125 \mathrm{MHz}\right): \delta$ 112.71 (C-1), 114.81 (C-9a), 115.81 (C-7), 130.98 (C-4a), 136.61 (C-8), 136.66 (C-9), 136.70 (C-3), 151.89 (C-4), 152.54 (C-2), 152.64 (C-6), 168.45 (C- $\alpha$ ), 181.98 (C-5). HPLC analysis was performed to confirm the presence of PGCA in IS. The chromatogram was measured at $400 \mathrm{~nm}$ ( $\lambda$ max of PGCA). Conditions: reversed-phase column (Develosil HG-5 $4.6 \mathrm{~mm}$ i.d. $\times 250 \mathrm{~mm}$ ); linear gradient elution for $45 \mathrm{~min}$ from $5 \%$ to $90 \%$ methanol in $0.01 \%$ trifluoroacetic acid solution; flow rate $1 \mathrm{ml} / \mathrm{min}$. 
Antifungal assays

Forty milliliters of sterilized PDA medium was poured into a 15-cm-diameter petri dish. An ethanol solution of gallic acid, ellagic acid, or PGCA $(5 \mathrm{mg} / \mathrm{ml})$ was spread on PDA medium. After the ethanol was evaporated completely, $R$. quercivora was placed on the center of the petri dish and the dish was incubated at $28^{\circ} \mathrm{C}$ for 3 days. The experiments were performed in triplicate and the diameter of $R$. quercivora was measured every day.

\section{Statistical analysis}

Significant difference between control and samples (gallic acid, ellagic acid, and PGCA) was assessed by one-way analysis of variance and $P<0.05$ was considered as significant.

\section{Results and discussion}

Total phenol, total flavanol values, and BSA adsorption of extracts of Quercus crispula sapwood

Some chemical analyses were conducted on the extracts from normal sapwood (NS) and infected colored sapwood (IS) (Table 1). Total phenol content of NS and IS extracts were $47.3 \%$ and $85.6 \%$, and their BSA precipitations were $59.3 \%$ and $71.6 \%$, respectively. On the other hand, total flavanol content of both extracts were less than $1 \%$ based on the extracts. Judging from the result, the extracts of $Q$. crispula showed little or no flavanol content, so the extracts would not contain condensed tannins. Therefore, these results indicate that NS and IS extracts contain hydrolysable tannin-like substances (not proanthocyanidin type).

\section{Comparison of NS and IS extracts by HPLC}

According to HPLC analysis (Fig. 2) with a photodiode array monitor, there were several phenolic compounds with $\lambda$ max values above $300 \mathrm{~nm}$ in the NS and IS extracts. However, chromatographically there was a difference between these two extracts; in the NS chromatogram, broad peaks appeared at a retention time of about $30 \mathrm{~min}$. On the other hand, the HPLC chromatogram of the hydrolysate of $\mathrm{NS}$, hydrolyzed with $3 \mathrm{~N}$ sulfuric acid, shows that there are several peaks related to phenolics, and ellagic acid a small amount of gallic acid are also present. Therefore, hydro-

Table 1. Chemical analysis of the extracts of Quercus crispula

\begin{tabular}{llll}
\hline Sample & $\begin{array}{l}\text { Total phenol } \\
(\%)\end{array}$ & $\begin{array}{l}\text { Total flavanol } \\
(\%)\end{array}$ & $\begin{array}{l}\text { Protein precipitation } \\
(\%)^{\mathrm{a}}\end{array}$ \\
\hline NS & 47.3 & 0.18 & 59.3 \\
IS & 85.6 & 0.25 & 71.6 \\
\hline
\end{tabular}

Data expressed as percentage based on dry NS and IS

NS, Normal sapwood; IS, infected colored sapwood

${ }^{a}$ Calculated as described in text lysable tannins, especially ellagitannins, exist in the NS extracts.

Quantity of PGG and gallic acid in the culture medium of Raffaelea quercivora

Hydrolysable tannins are classified roughly into gallotannins and ellagitannins. PGG is a representative gallotannin and a constituent of commercial tannic acid.

After PGG was added to the culture medium $(4 \mu \mathrm{g} / 10 \mathrm{ml}$ culture medium) of Raffaelea quercivora, the amounts of PGG and gallic acid were measured over time by HPLC and are shown in Fig. 3. The amount of PGG fell to half in $11 \mathrm{~h}$ and completely disappeared in 2 days. On the contrary, the amount of gallic acid increased gradually, suggesting that $R$. quercivora produces hydrolytic enzyme, such as tannase, in the culture medium.

On the other hand, the amount of gallic acid was increased with the decrease of PGG, reached a maximum at 5 days, and disappeared after 11 days of incubation. Theoretically, 5 moles of gallic acid is produced from 1 mole of PGG by hydrolysis. In this experiment, $4 \mathrm{mg}(4.26 \mu \mathrm{mol}$, $0 \mathrm{~h}$ ) of PGG was hydrolyzed to produce only $9.08 \mu \mathrm{mol}$ of

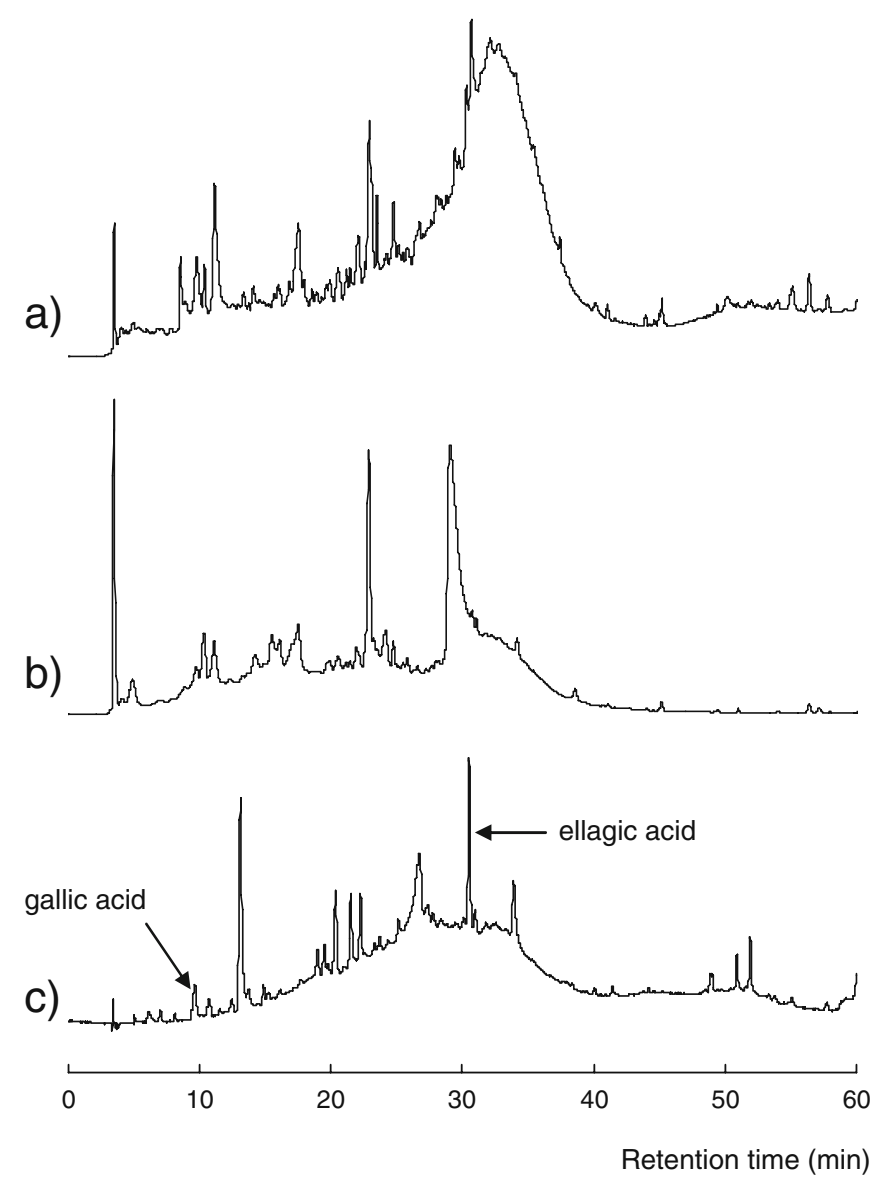

Fig. 2a-c. High performance liquid chromatography (HPLC) chromatograms of extracts from $Q$. crispula sapwood with detection at $280 \mathrm{~nm}$. a Extracts from normal sapwood of $Q$. crispula (NS); b extracts from infected colored sapwood of $Q$. crispula (IS); c NS hydrolyzed with $3 \mathrm{~N} \mathrm{H}_{2} \mathrm{SO}_{4}$ at $110^{\circ} \mathrm{C}$ for $10 \mathrm{~h}$ 


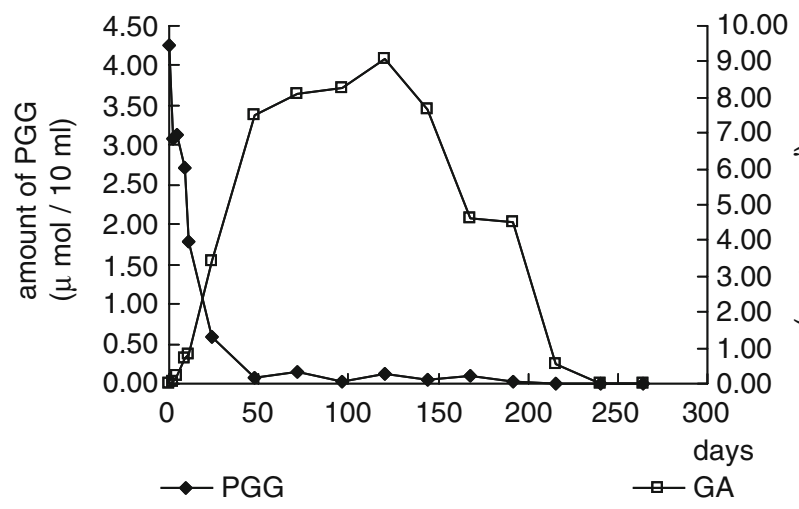

Fig. 3. Amount of pentagalloyl glucose $(P G G)$ and gallic acid $(G A)$ in the culture medium of $R$. quercivora

gallic acid as a maximum $(120 \mathrm{~h})$. Therefore, production and consumption of gallic acid must have taken place at the same time in the culture medium.

Characteristic property of tannase-like enzyme from Raffaelea quercivora

Crude enzyme solution from $R$. quercivora showed tannaselike activity for PGG. In order to confirm the activity of the crude enzyme solution against the extracts of $Q$. crispula, EtOAc-S was treated with the crude enzyme solution.

Figure 4 shows the HPLC chromatograms of the EtOAc$\mathrm{S}$ solution treated with the crude enzyme of $R$. quercivora or commercial tannase derived from Aspergillus oryzae. In treating EtOAc-S with the crude enzyme, a small amount of gallic acid $\left(R_{\mathrm{f}} 10 \mathrm{~min}\right)$ and a large amount of ellagic acid $\left(R_{\mathrm{f}} 31 \mathrm{~min}\right)$ were produced with a decreasing series of peaks at around $30 \mathrm{~min}$ retention time. On the other hand, a remarkable amount of gallic acid and little or no ellagic acid were produced with a slight decrease of the series of peaks in case of using commercial tannase. It is possible that a tannase of $R$. quercivora may have a unique ability to hydrolyze both gallotannins and ellagitannins.

\section{Crude enzyme activity of Raffaelea quercivora}

In a manner that is similar to the hydrolysis of PGG as shown in Fig. 3, the amount of gallic acid produced from EtOAc-S and the crude enzyme of $R$. quercivora increased up to a specific incubation time, after which it decreased gradually and finally disappeared (data not shown). Such a decrease in gallic acid could be due to the presence of phenol oxidase in the crude enzyme solution. Figure 5 shows the tannase and laccase activities of the crude enzyme solution for 10 days. The tannase activity of $R$. quercivora gradually increased from the beginning of the incubation and peaked on the sixth day of incubation. Peroxidase activity was not detected. The crude enzyme solution has laccase activity which shows a drastic increase on the sixth day of incubation. It is indicated that $R$. quercivora has the ability to produce tannase and laccase.

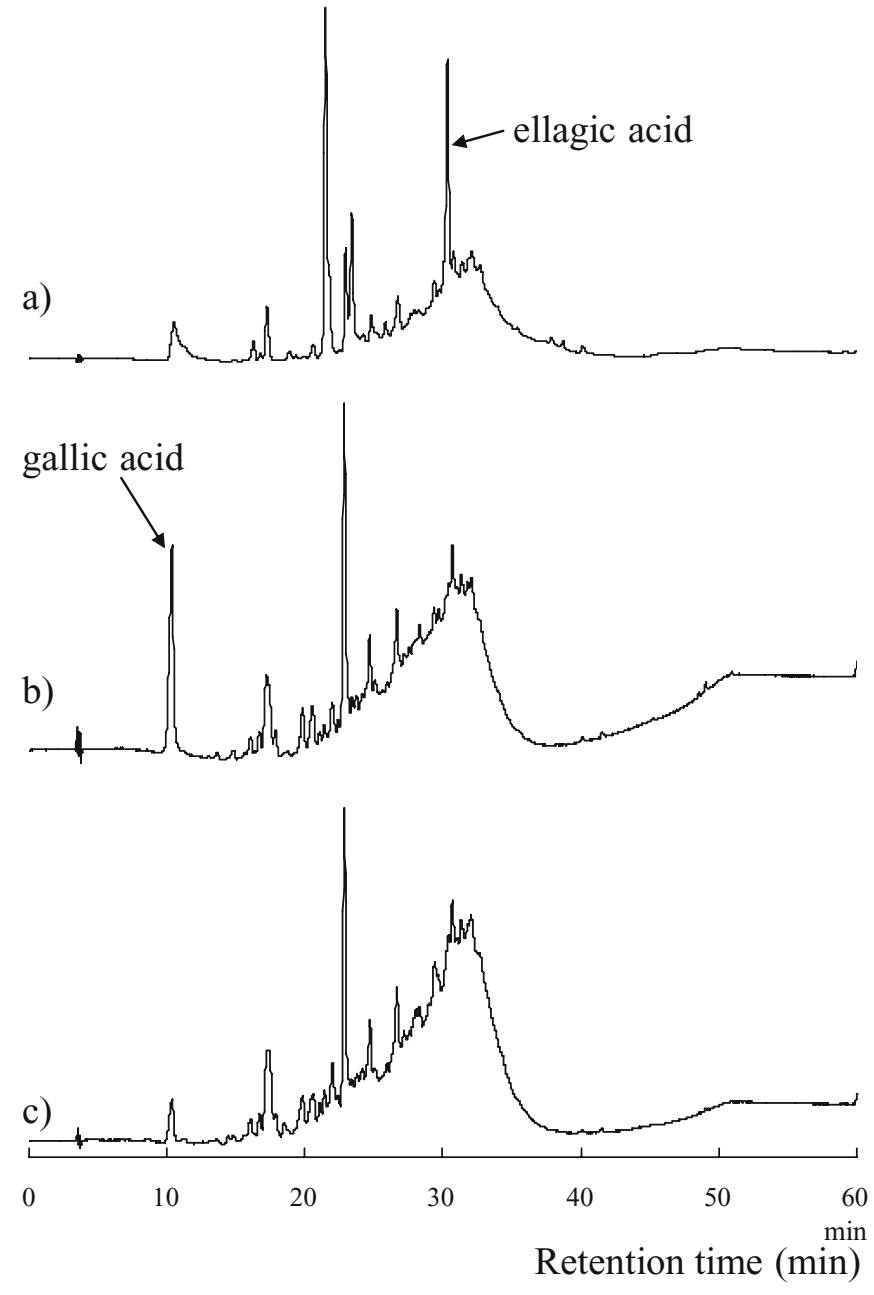

Fig. 4a-c. HPLC chromatograms of the ethyl acetate-soluble extract of normal sapwood (EtOAc-S) treated with a crude enzyme of $R$. quercivora, b commercial tannase. c Blank

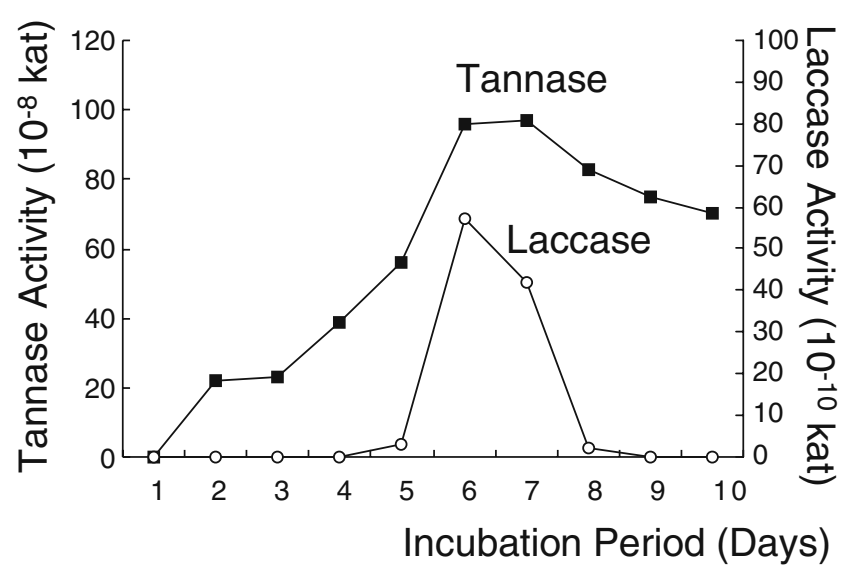

Fig. 5. Tannase and laccase activities in crude enzyme solution of $R$. quercivora incubated at $35^{\circ} \mathrm{C}$

Identification of purprogallincarboxylic acid

The enzymatic oxidation of gallic acid with the laccase was performed for 7 days at room temperature. Addition of laccase solution to gallic acid solution gradually darkened 


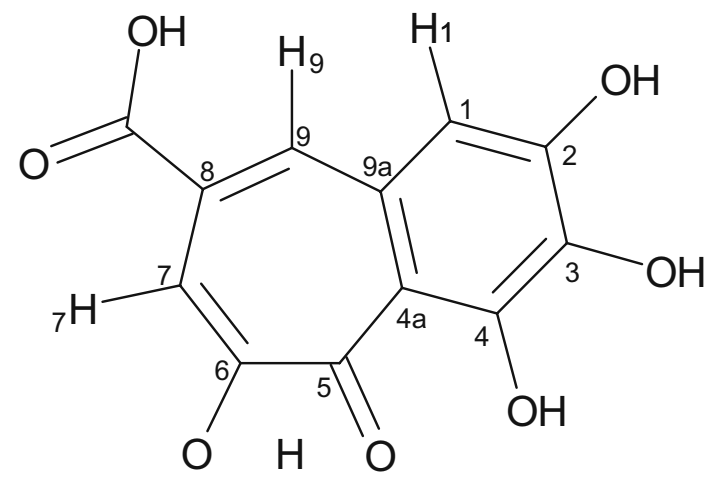

Fig. 6. Structure of purprogallincarboxylic acid (PGCA)

the color of the reaction mixture. One compound with $\lambda \max$ values of 224,304, and $398 \mathrm{~nm}$ was found by HPLC analysis of the colored reaction mixture. The ${ }^{1} \mathrm{H}$ NMR spectrum showed three singlets at 7.14, 7.77, and $8.22 \mathrm{ppm}$ and no other proton resonance was observed. Twelve carbon signals including a carboxyl group at $160 \mathrm{ppm}$ and a conjugated carbonyl group at $182 \mathrm{ppm}$ were observed in the ${ }^{13} \mathrm{C}$ NMR spectrum. According to the $\mathrm{C}-\mathrm{H}$ COSY twodimensional (2D) correlation spectrum and the DEPT NMR spectrum, the three protons are directly attached to each corresponding methine carbon $(\mathrm{H}-\mathrm{C}$ correlations: ${ }^{1} \mathrm{H} 7.14 \mathrm{ppm}$ and ${ }^{13} \mathrm{C} 112.71 \mathrm{ppm},{ }^{1} \mathrm{H} 7.77 \mathrm{ppm}$ and ${ }^{13} \mathrm{C}$ $115.81 \mathrm{ppm}$, and ${ }^{1} \mathrm{H} 8.22 \mathrm{ppm}$ and $\left.{ }^{13} \mathrm{C} 136.66 \mathrm{ppm}\right)$. By understanding $\mathrm{C}-\mathrm{H}$ correlations with heteronuclear multibond correlation (HMBC) 2D NMR spectroscopy, some partial structures of the compound were clarified. Although it was impossible to observe the molecular ion peak by EIMS, all information indicated the compound was purprogallincarboxylic acid (Fig. 6), which was identified and reported as an oxidative product from gallic acid converted with a polyphenol oxidase from potato. ${ }^{17}$

According to the HPLC analysis with detection at $400 \mathrm{~nm}$, the water-soluble fraction of IS extracts showed a well-defined peak at a retention time of $28 \mathrm{~min}$ (Compound 1) as shown in Fig. 7. The UV spectrum and retention time in HPLC of Compound 1 conformed with those of PGCA. This suggests that PGCA is present in infected colored sapwood of Q. crispula, and indicates that PGCA is a significant contributor to the coloration caused by $R$. quercivora in diseased sapwood of Q. crispula.

Antifungal activities of gallic acid, ellagic acid, and PGCA

Figure 8 shows the antifungal activities of gallic acid, ellagic acid, and PGCA against $R$. quercivora. After 1 day of incubation, the mycelium diameters were almost the same, but after 3 days of incubation, gallic acid inhibited the mycelium growth by about $43 \%$, ellagic acid by about $45 \%$, and PGCA by about $28 \%$. This suggests that gallic acid and ellagic acid have antimicrobial activities against $R$. quercivora (significantly different from control; $P<0.05$ ). Compared with the antimicrobial activities of gallic acid and

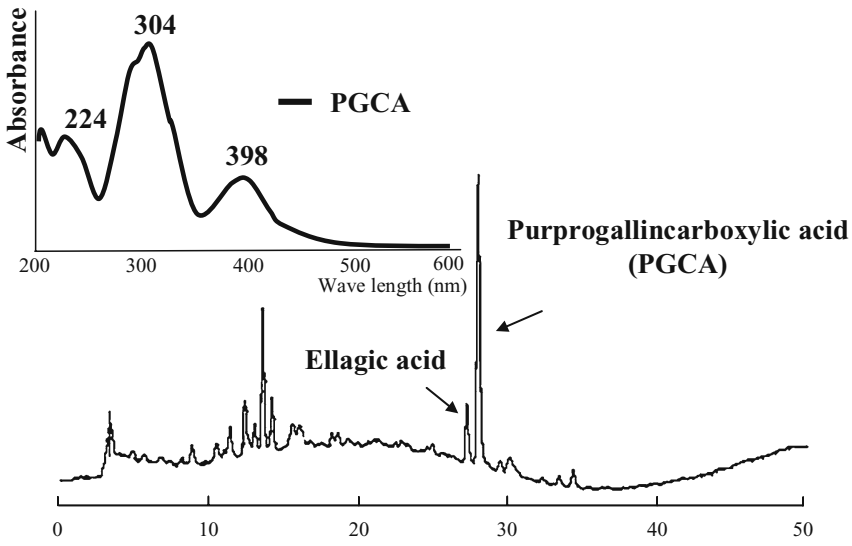

Fig. 7. HPLC chromatogram with detection at $400 \mathrm{~nm}$ of the watersoluble fraction of IS extracts. The ultraviolet absorption spectrum and the HPLC retention time of Compound 1 conformed with those of PGCA

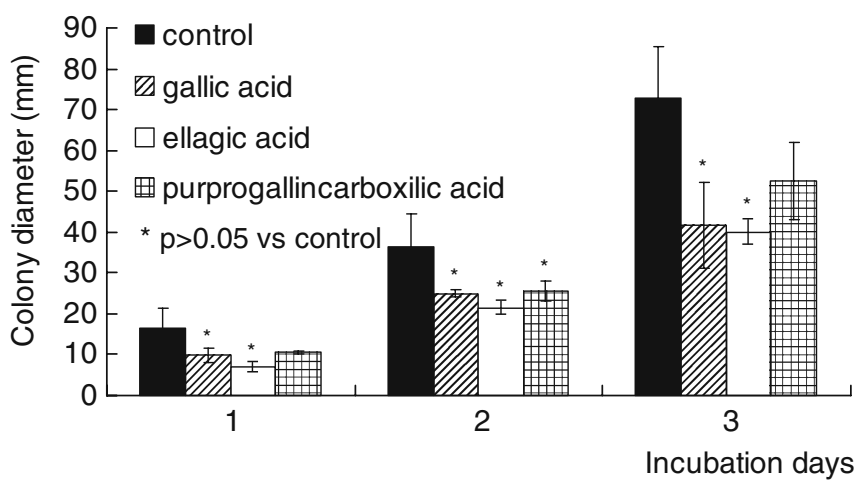

Fig. 8. Antifungal activities of gallic acid, ellagic acid, and PGCA against $R$. quercivora

ellagic acid, that of PGCA was lower and was not significantly different from the control.

Gallic acid has antimicrobial activity against some microorganisms, including Staphylococcus aureus, ${ }^{18}$ Escherichia coli ${ }^{18}$ and Fusarium fusiformis. ${ }^{19}$ It was thought that gallic acid might also be toxic against $R$. quercivora; thus, it appears that $R$. quercivora is equipped with the means to change the toxic compound (gallic acid) into the low toxicity compound (PGCA).

In conclusion, $R$. quercivora hydrolyzes hydrolysable tannins to produce gallic and ellagic acids in sapwood and prevents the formation of complex products from reaction between enzymes and tannins. However, the resulting polyphenols are not favorable for growth of $R$. quercivora, so the fungus converts the polyphenols into nontoxic compounds by enzymatic oxidation, which causes coloration of the sapwood.

Acknowledgments The authors are grateful to Dr. Koji Takabata (Toyama Forestry and Forest Products Research Center) for providing the infected $Q$. crispula plants. This research was partially supported by the Ministry of Education, Culture, Sports, Science and Technology, Japan, and a Grant-in-Aid for Scientific Research (B), 16380096. 


\section{References}

1. Ito S, Kubono T, Sahashi N, Yamada T (1998) Associated fungi with the mass mortality of oak trees (in Japanese). J Jpn For Soc 80:170-175

2. Kubono T, Ito S (2002) Raffaelea quercivora sp. nov. associated with mortality of Japanese oak and the ambrosia beetle (Platypus quercivorus). Mycoscience 43:255-260

3. Bauch J (1986) Verfärbungen von Rund- und Schnittholz und Möglichkeiten für vorbeugende Schutzmaßnahmen. HolzZentralbl 112:2217-2218

4. Armondo GM, Marc F, Bernhard K (1997) Chemical and UV-VIS spectroscopic study on kiln brown stain formation in radiata pine. In: Proceedings of the 9th International Symposium of Wood and Pulping Chemistry. Montreal, Canada, June 9-12, pp 70.1-70.5

5. Lidija M (1975) Formation of tyloses in felled Quercus rubra L. Wood Sci Technol 9:3-14

6. Armondo GM, Marc F, Bernhard K, Frank L (2000) The chemical nature of kiln brown stain in radiata pine. Holzforschung 54: $12-22$

7. Rizzi GP (1994) The Maillard reactions in food. In: Labuza TP, Reineccius GA, Morrier VM, O'Brien J, Baynes JW (eds) Maillard reactions in chemistry, food and health. Royal Society of Chemistry, Cambridge, UK, pp 11-19

8. Threander O, Nelson DA (1988) Aqueous high temperature transformation of carbohydrates relative to utilisation of biomass. Adv Carbohydr Chem Biochem 46:273-326

9. Murray LL, Durria AAM (1996) An enzyme extract from Douglasfir sapwood and its relationship to brown staining. Wood Fiber Sci 28:2-6
10. Laver ML, Durria AAM (1997) Chemical brown staining of Douglas-fir wood: characterization of a wood enzyme extract. Forest Prod J 47:93-97

11. Bauch J, Hundt H, Weissmann G, Lange W, Kubel H (1991) On the causes of yellow discolourations of oak heartwood (Quercus sect. robur) during drying. Holzforschung 45:79-85

12. Battestin V, Macedo GA (2006) Tannase production by Paecilomyces variotii. Bioresource Technol 98:1832-1837

13. Takagi K, Shimomura K, Koizumi Y, Mitsunaga T, Abe I (1999) Tyrosinase inhibitors from the pericarp of jatoba (Hymenaea courbaril L.) (in Japanese with English summary). Nat Med 53:15-21

14. Takagi K, Mitsunaga T (2002) A tyrosinase inhibitor from the asam (Mangifera quadrifida). Nat Med 56:97-103

15. Richard T, Vitrac X, Merillon JM, Monti JP (2005) Role of peptide primary sequence in polyphenol-protein recognition: an example with neurotensin. Biochim Biophys Acta 1726:238-243

16. Yoshihara I, Akamatsu I, Ueshima H, Fujii T (1985) Screening of white rot fungi which has strong resolution activity against lignin (in Japanese). Jpn TAPPI J 39:65-74

17. Karl H (1954) Über die Bildung der Purpurogallincarbonsäure durch fermentative Oxydation der Gallussäure. (zugleich II Mitteilung über gerbstoffartige Substanzen). Archiv der Pharmazie 287:497-503

18. Panizzi L, Caponi C, Catalano S, Cioni PL, Morelli I (2002) In vitro antimicrobial activity of extracts and isolation constituents of Rubus ulmifolius. J Ethnopharmacol 79:165-168

19. Shukla YN, Anil S, Sunil K, Susil K (1999) Phytotoxic and antimicrobial constituents of Argyreia speciosa and Oenothera biennis. J Ethnopharmacol 67:241-245 